\title{
A viabilidade do casamento homoafetivo no direito civil constitucional brasileiro: a busca real do direito à felicidade
}

Edson Camara de Drummond ALVES JUNIOR*

\begin{abstract}
*Advogado (licenciado) e Professor de Direito Civil da Universidade Vale do Rio Verde (UNINCOR-MG). Bacharel em Direito pelas Faculdades Integradas Vianna Junior (FIVJ-MG) e Especialista em Direito Civil e Processual Civil pela Universidade Candido Mendes (UCAM-RJ) - e-mail: edsondrummondjr@hotmail.com.
\end{abstract}

Recebido em: 14/01/2013 - Aprovado em: 27/05/2013 - Disponibilizado em: 15/08/2013

\section{RESUMO:}

Diante deste fato social, que remonta desde a Antiguidade, nas polis gregas, e protegido, atualmente, por diversas legislações alienígenas, ao redor do mundo, o atual Estado brasileiro não poderá ficar indiferente a proteger as uniões homoafetivas, que apresentam todas as características e requisitos comuns às heterossexuais, para constituição de uma entidade familiar, célula mater social, baseada no amor entre seus membros, onde muitos casais do mesmo sexo buscam formalizar suas situações e todas as consequências jurídicas que possam advir disto, perante à sociedade brasileira, por meio do instituto do casamento, fazendo valer, assim, suas cidadanias e a busca real ao direito fundamental e universal, assegurado a todos, à felicidade, e que esbarram no equivocado entendimento de alguns agentes públicos que justificam sua conduta diante da omissão legislativa estatal e, muitas vezes, por questões de fundo religioso e pseudo-moralista, mesmo diante de recente decisão do Supremo Tribunal Federal que contraria tal posicionamento, reafirmando a Alta Corte a sua posição de garantidor da Lei Maior e da sociedade brasileira, representada, no caso em tela, por uma numerosa parcela.

Palavras-chave: Casamento. Homoafetividade. União Estável. Felicidade. Direito fundamental.

\section{ABSTRACT:}

In front of this social fact, dating from antiquity, in the Greek polis, and protected, nowadays, by various aliens laws, all around the world, the current brazilian state cannot remain indifferent of protecting gays unions, which have all the features and requirements common to heterosexual to set up an entity familiar social mother cell, based on love between its members, where many same-sex couples are trying to formalize their situations and obtaining all legal consequences that may arise from this, in the brazilian society, through the institution of marriage, enforcing thus their citizenship and to search real fundamental and universal right, guaranteed to all, of the happiness, and that is blocked in the mistaken understanding of certain public agents who justify their conduct with the state legislative omission and, often, for reasons of religious background and pseudo-moralistic, even before the recent Supreme Court's decision that contradicts this position, the Higher Court reaffirming its position as the keeper of the Higher Law and brazilian society, represented, in this case, by a large parcel.

Key words: Marriage. Sexual fondness. Stable union. Happiness. Fundamental right.

A família, objeto do ramo do

Direito Civil intitulado como Direito das

Famílias (nomenclatura essa bem elaborada

pela doutrinadora Maria Berenice Dias, em obra de mesmo nome), como instituição social comum a sociedades e culturas tão diversas, é de difícil conceituação, pois não está ligada, necessariamente, a um fenômeno jurídico ou a uma relação de parentesco. Devemos lembrar, ainda, que o "ideal" de família constituída pelos pais e seus filhos, com fundamento nos ideais patrimonialista $\mathrm{e}$ patriarcal monogâmica, remonta da longingua coletividade romana.

Contudo, com o passar dos anos, essa "romantização" (ou mais acertadamente "romanização") da estrutura familiar referida acima passou a ser descaracterizada em função de diversos fatores ocorridos, em nível global (principalmente após a Revolução 
Industrial ocorrida no século XVIII e acelerada com a Revolução Sexual, nos idos de 1960), como, por exemplo, a diminuição do número de filhos (assim como muitas famílias optaram por não o terem) em razão de a sociedade, em seus primórdios, ser eminentemente rural, e que cada filho havido constituía, desta maneira, primeiramente, mão-de-obra e também perpetuação dos bens adquiridos naquele clã (caráter patrimonial), perdendo-se essa característica com a frenética urbanização ocorrida com o passar dos séculos; assim como com o crescimento da importância e participação econômica da mulher (com a sua inserção no mercado de trabalho), quebrando-se a famosa imagem patriarcal do homem como figura central e importante da entidade familiar. Nos dias atuais, diferentemente, a família vincula os seus membros, exclusivamente, por meio de solidariedade, amor, companheirismo e afeto entre os mesmos.

Independentemente da família não estar mais associada somente à imagem "pais e filhos", mesmo assim, é, ainda, considerada como a base da sociedade e que, por isso, deve ter uma proteção especial estatal para se manter intacta. Para isso, foram criados diversos mecanismos, dentre os quais, jurídicos, a níveis nacional e internacional, como a Declaração Universal dos Direitos Humanos, em seus artigos XII e XVI ${ }^{\mathrm{i}}$, que, mesmo não tendo uma coercibilidade na sua aplicabilidade, constitui importante direcionamento aos Estados para criarem leis e, desta forma, salvaguardar a entidade familiar.

Outra forma existente de regular e, assim, proteger a entidade familiar pelo Estado (diga-se, de passagem, a sua base), foi a criação, por este, como bem salientado por Maria Berenice Dias (apud LIRA e CHAGAS, 2012) do instituto do casamento, como meio de organização e limite nos vínculos interpessoais, impondo-se, assim, regras de convívio ao casal, com a finalidade de se evitar a sua dissolução. Contudo, essa instituição foi concebida sob o ditame do modelo primitivo adotado pela doutrina judaico-cristã (a seu turno, influenciada pelas regras da sociedade romana, como visto anteriormente), qual seja, a união entre um homem e uma mulher (heterossexual) com o intuito exclusivo de reprodução, conforme elucida Fernanda de Almeida Brito (apud LIRA e CHAGAS, 2012) ao afirmar que:

Toda a prática sexual entre os judeus só poderia ser admitida com a finalidade de procriação. Qualquer atividade sexual que desperdiçasse sêmen seria condenada.

Não podendo ser diferente, o Estado brasileiro também regulou a proteção estatal à família, quando, primeiramente, no artigo 226 da Constituição da República Federativa do Brasil de 1988 afirmou que a entidade familiar é sua base e que por isso deve ter guarida; ainda, em seus $\S \S^{\circ}$ e $2^{\circ}$, 
determina-se que o casamento será civil e gratuita a sua celebração e quando realizado somente de forma religiosa, terá efeitos civis, na forma determinada em lei. A seu turno, o Código Civil também regulou o casamento e, por consequência, a família, em capítulo próprio (Livro IV, Título I, Subtítulo I). Porém, o mais interessante, ao se analisar a legislação nacional (assim como a internacional) acerca do tema, é que não se encontra qualquer definição precisa sobre o que constitui família, relegando tal tarefa ao operador do Direito, no caso em concreto. Para corroborar com tal afirmativa, a nossa própria Lei Maior, no citado artigo, admite também como entidade familiar (e, por isso, objeto de proteção), não somente aquela advinda do casamento, mas também a constituída por qualquer um dos pais e seus filhos (monoparental) e a união estável entre o homem e a mulher $\left(\S \S 4^{\circ}\right.$ e $3^{\circ}$, respectivamente), devendo, nessa última hipótese, ocorrer a facilitação da sua conversão em casamento. Ainda, somente podemos deduzir do nosso conjunto normativo acerca do tema em comento que o elemento formador e agregador de seus membros é o amor familiar, ou seja, que tenham como finalidade a comunhão pública, contínua e duradoura plena de interesses na vida privada (sendo esse, também, o fundamento da lei nacional 11.340/2006, ao tratar de coibir a violência doméstica - Lei Maria da Penha - inclusive, com a previsão textual da entidade familiar homoafetiva, em seu artigos $02^{\circ}$ e $05^{\circ}, \S$ único).

Por nossa doutrina, hoje, ao se analisar o instituto do casamento, verifica-se, majoritariamente, o entendimento de que o mesmo constitui como a união formal e permanente entre um homem e uma mulher com a finalidade, única e exclusivamente, de constituir uma família, ou seja, independe do caráter reprodutor e patrimonial, que poderia existir na legislação, anteriormente. Nesse sentido, é a lição de Cézar Fiúza (apud LIRA e CHAGAS, 2012) quando afirma que em nosso ordenamento jurídico nacional “casamento é a união estável e formal entre homem e mulher, com o objetivo de satisfazer-se e amparar-se mutuamente, constituindo família”. Qualquer forma diferente desta, em que não haja a necessária dualidade sexual, constituiria o chamado “casamento inexistente". Contudo, essa é uma visão de doutrinadores, não tendo qualquer relação com a legislação, pois, conforme anteriormente admitido, nem a Constituição da República Federativa do Brasil de 1988, assim como o próprio Código Civil, possuem qualquer definição para esse instituto social, quiçá a necessidade da diversidade de sexos entre os nubentes (diferentemente do que ocorria em Portugal, por exemplo, que havia determinação legal expressa, para que um casamento fosse considerado válido, da dualidade sexual). 
E, é aqui, que se encontra a problemática sugerida neste trabalho, pois diante do fato social da existência de pares homossexuais (fato social esse que remonta desde a Grécia Antiga, quando era considerada a homessexualidade como prática natural e cotidiana entre guerreiros espartanos e filósofos gregos, dentre os quais, Platão, e que, lado outro, inclusive, ao longo da história da humanidade, fora alvo de preconceito e de discriminação, como nas Inquisições e que, atualmente, são, socialmente, aceitas suas manifestações, vide as paradas gays realizadas, anualmente, em diversos países, inclusive no Brasil, com grande repercussão em São Paulo e no Rio de Janeiro), estariam os mesmos amparados sob todos os aspectos ou não por nossa legislação, haja vista, não haver previsão legal da possibilidade da formalização da união homoafetiva em nosso ordenamento jurídico? Poderiam, os mesmos, formalizar uniões, muitas vezes, públicas e notórias, efetivando-se, desta feita, diversos direitos daí oriundos, como, por exemplo, de natureza previdenciária ou sucessória no Direito brasileiro, através do casamento (independentemente de ser constituída como uma sociedade de fato, na figura de sócios)?

$$
\text { Para respondermos }
$$

adequadamente a essas indagações, devemos, inicialmente, relembrar importante decisão tomada, recentemente, pelo Supremo Tribunal Federal (em 05 de novembro de 2011), que, por unanimidade, reconheceu a união estável ii entre pessoas do mesmo sexo, constituindose, assim, entidade familiar (merecedora, portanto, de proteção estatal), ao se manifestar, conjuntamente, acerca da Ação Direta de Inconstitucionalidade 4.277 (instrumentalizada pelo Procurador Geral da República) e na Arguição de Descumprimento de Preceito Fundamental 132 (ajuizada pelo Governador do Estado do Rio de Janeiro, Sérgio Cabral Filho), constituindo-se em importante vitória ao movimento LGBTT. Portanto, para a Corte Constitucional, da união homoafetiva decorrem os mesmos direitos e deveres que provêm da união estável entre um homem e uma mulher, desde que, logicamente, aquela se caracterize pela convivência pública, contínua e duradoura entre seus membros, com a finalidade de constituir família, conforme determina o artigo 1.723 do Código Civil.

E o casamento entre pessoas do mesmo sexo? De maneira direta, o Supremo Tribunal Federal não se manifestou acerca do tema, contudo, ao se analisar mencionada decisão e todo o ordenamento jurídico nacional que a fundamentou, podemos concluir em um único sentido: a viabilidade do casamento homossexual. Explica-se: conforme mencionado anteriormente, o artigo 226, § $3^{\text {o }}$ da Constituição da República Federativa do Brasil de 1988 (corroborado pelo artigo 1.726 do Código Civil) determina que a legislação infra-constitucional deve facilitar a conversão da união estável entre um 
homem e uma mulher em casamento e, portanto, com o entendimento da Corte Constitucional visto, por lógica, concluímos que poderá ocorrer a conversão, também, da união homoafetiva, sob pena de se ferir o princípio da isonomia reinante em nosso ordenamento (além do fato de não existir qualquer tipo de proibição - impedimento na lei nacional 10.406/2002 a esse tipo de matrimônio, em seu artigo 1.521).

Porém, o casamento entre pessoas do mesmo sexo ficaria restrito somente à hipótese da conversão da união estável? Primeiramente, o casal deveria se unir, demonstrando os atributos necessários ao reconhecimento da estabilidade da relação (convivência pública, contínua, duradoura e com o fim de constituir família) para, posteriormente, requerer a sua transmutação? Não haveria qualquer possibilidade do casamento direto? Mais uma vez, por meio da hermenêutica jurídica, a resposta a essas indagações seria um sonoro NÃO, pois, mesmo não havendo a previsão legal da sua existência ou sua proibição, mas entendendo que o rol da família elencado pelo artigo 226 da Lei Maior brasileira não é taxativo, mas, sim, meramente exemplificativo, e com fundamento nos princípios da isonomia, da dignidade da pessoa humana, na liberdade individual particular, da autonomia de vontade e não discriminação sexual, é possível o casamento direto homossexual. Ademais, é somente se verificar que o mencionado dispositivo constitucional não mencionou a necessidade da dualidade sexual (homem e mulher) à constituição de família, como o fez ao se referir à união estável e, ainda assim, o procedeu nesta hipótese, conforme afirmou o Ministro Ayres Britto do Supremo Tribunal Federal (apud CHAVES, 2011), somente para reforçar o ideal de igualdade entre os sexos e não qualquer tipo de conotação heterossexual para reduzir a sua dimensão.

Portanto, podemos concluir que nossa legislação, ao regular o casamento, mesmo não havendo previsão expressa (temse projetos de lei e de Emenda Constitucional em tramitação no Congresso Nacional desde a década de 1990, evidenciando-se a morosidade legislativa em importante questão), pela hermenêutica jurídica, em nenhum momento, veda ou dificulta a formalização da união de pessoas do mesmo sexo, que constituam vínculos perenes, com fundamento no amor e assistência recíproca, e que tenham planejado uma vida em comum, constituindo-se, assim, entidade familiar, podendo o casamento homoafetivo advir diretamente ou mediante conversão de anterior união estável. O Estado brasileiro, acompanhando diversos outros como Espanha, Portugal, Argentina, Canadá e África do Sul, e diante da tramsmutação do nosso Direito das Famílias, com respaldo na constitucionalização do Direito Civil, deverá respaldar seus cidadãos, mediante ações 
afirmativas no sentido de proteger os mesmos de qualquer atitude discriminatória, inclusive, de seus próprios agentes (com exceção, notadamente, dos membros do Poder Judiciário, por meio do chamado "ativismo judicial), que por um equivocado entendimento (por entenderem, muitas vezes, que há uma omissão legislativa, impedindo, assim, a sua efetivação ou em uma

\section{REFERÊNCIAS BIBLIOGRÁFICAS}

BRASIL. Código Civil. Vade mecum compacto de Direito. 03 ed. São Paulo: Rideel, 2012.

. Constituição (1988). Vade mecum compacto de Direito. 03 ed. São Paulo: Rideel, 2012.

Lei 11.340, de 07 de agosto de 2006. Vade mecum compacto de Direito. 03 ed. São Paulo: Rideel, 2012.

CHAVES, Marianna. O julgamento da ADPF 132 e da ADI 4277 e seus reflexos na seara do casamento civil. Jus Navigandi, 2011. Disponível em: <http://jus.com.br/revista/texto/20672>. Acesso em: 7 jan. 2013, 16:30:30.

DIAS, Maria Berenice. Homoafetividade: casamento sem escala. Jus Navigandi, 2011. Disponível em:

<http://jus.com.br/revista/texto/20303>. Acesso em: 7 jan. 2013, 17:45: 15.

FIUZA, César. Direito Civil: curso completo. 07 ed. Belo Horizonte: Del Rey, 2003.

GONÇALVES, Carlos Roberto. Direito de família. vol. II. 14 ed. São Paulo: Saraiva, 2010. fundamentação pseudo-moralista iii), negam ou dificultam a consecução por parte de casais do mesmo sexo do direito fundamental (mesmo não previsto em nossa Lei Maior, de maneira expressa) universal e absoluto à busca real da felicidade, consubstanciado na expressão de sua orientação sexual e, por conseguinte, de sua cidadania.

KOIKE, Maria Lygia de Almeida. Caso Salgueiro Mouta versus Portugal: uma relação paternal homoafetiva perante 0 Tribunal Europeu dos Direitos do Homem. Jus Navigandi, 2012. Disponível em: <http://jus.com.br/revista/texto/22706>. Acesso em: 2 jan. 2013, 15:30: 52.

LIRA, Penélope Aryadne Antony; CHAGAS, Yonete Melo das. A viabilidade do casamento civil entre os pares homoafetivos. Jus Navigandi, 2012. Disponível em: $<$ http://jus.com.br/revista/texto/21879>. Acesso em: 2 jan. 2013, 15: 22: 34.

ORGANIZAÇÃO DAS NAÇÕES UNIDAS. Declaração universal dos direitos humanos. Disponível em:

$<$ http://portal.mj.gov.br/sedh/ct/legis_intern/d dh_bib_inter_universal.htm>. Acesso em: 14 jan. 2013.

SOUZA, Alécio Pereira de. Casamento entre pessoas de mesmo sexo: breves considerações acerca da viabilidade constitucional da positivação do casamento entre pessoas de mesmo sexo no ordenamento jurídico brasileiro. Jus Navigandi, 2012 . Disponível em: $<$ http://jus.com.br/revista/texto/21881>. Acesso em: 4 jan. 2013, 18: 15: 32.

\footnotetext{
${ }^{\text {i }}$ Artigo XII: "Ninguém será sujeito a interferências na sua vida privada, na sua família, no seu lar ou na sua correspondência, nem a ataques à sua honra e reputação. Toda pessoa tem direito à proteção da lei contra tais interferências ou ataques". Artigo XVI: "1. Os homens e mulheres de maior idade, sem qualquer
} 
retrição de raça, nacionalidade ou religião, têm o direito de contrair matrimônio e fundar uma família. Gozam de iguais direitos em relação ao casamento, sua duração e sua dissolução. 2. O casamento não será válido senão com o livre e pleno consentimento dos nubentes"

ii A união estável se caracteriza pela relação entre os companheiros (podendo ser pessoas solteiras, viúvas, divorciadas e as separadas judicialmente ou de fato), sob a mesma moradia ou não, que não são vinculados pelo casamento, contudo, tenham todas as características do mesmo (mos uxorius), independente de lapso temporal de convivência ou da existência de filhos, com a finalidade de constituir família, diferentemente, portanto, de um simples namoro ou mesmo noivado. Diante desta situação, os seus participantes possuem direito a alimentos e a suceder um ao outro. Difere do chamado "concubinato", previsto no art. 1.727 do Código Civil, que nas palavras de Carlos Roberto Gonçalves (2010, p. 178), consubstancia-se no "relacionamento amoroso envolvendo pessoas casadas, que infringem o dever de fidelidade (adulterino) ".

iii Para César Fiúza (2003, p. 796): “A única regra moral é a do amor ao próximo. Tudo o que não ferir esta norma é moral, é permitido ou, quando nada, tolerado. $\mathrm{O}$ ser humano é responsável por seus atos e por seu destino. Cada indivíduo tem livre-arbítrio sobre sua vida e seus caminhos". 